\title{
A heteronuclear ZnGd complex as a potential contrast agent for magnetic resonance imaging
}

\author{
Matilde Fondo, ${ }^{\text {a }}$ Julio Corredoira, ${ }^{\text {a }}$ Ana M. García-Deibe, ${ }^{a}$ Jesús Sanmartín, ${ }^{\text {a }}$ Ramón \\ Iglesias, ${ }^{\mathrm{b}}$ Pablo Taboada ${ }^{\mathrm{c}}$ \\ ${ }^{a}$ Departamento de Química Inorgánica, Facultad de Química, Universidad de Santiago de \\ Compostela, E-15782 Santiago de Compostela, Spain \\ ${ }^{\mathrm{b}}$ Clinical Neurosciences Research Laboratory, Health Research Institute of Santiago de \\ Compostela (IDIS), Department of Neurology, Santiago de Compostela 15706, Spain \\ ${ }^{\mathrm{c}}$ Grupo de Física de Coloides y Polímeros, Departamento de Física de Partículas, \\ 15782-Santiago de Compostela, Spain \\ E-mail: matilde.fondo@usc.es
}

\begin{abstract}
A new ligand $\mathrm{H}_{3} \mathrm{~L}$, with internal compartments for allocating $3 d$ metal ions and external donors to bind $4 f$ ions, was synthesized and completely characterized. Reaction of $\mathrm{H}_{3} \mathrm{~L}$ with zinc(II) and gadolinium(III) salts allows isolating the heteronuclear complex $\left\{\left[\mathrm{ZnGd}(\mathrm{HL})\left(\mathrm{NO}_{3}\right)(\mathrm{OAc})\left(\mathrm{CH}_{3} \mathrm{OH}\right)\right]\left(\mathrm{NO}_{3}\right)\right\} \cdot 6 \mathrm{H}_{2} \mathrm{O}\left(\mathbf{1} \cdot 6 \mathrm{H}_{2} \mathrm{O}\right)$. The ability of $\mathbf{1} \cdot 6 \mathrm{H}_{2} \mathrm{O}$ to act as a magnetic resonance imaging (MRI) contrast agent was evaluated and this study shows that both the transversal and longitudinal relaxivities are quite high but the $T_{1} / T_{2}$ ratio of 7.9 indicates that it could have even greater potential as a $T_{2}$ contrast agent.
\end{abstract}

\section{Keywords}

Gadolinium, zinc, MRI contrast agent, Schiff base, imidazolidine

\section{Introduction}

The application of gadolinium(III) complexes as contrast agents (CAs) in magnetic resonance imaging requires stable complexation of the metal ion under physiological conditions to avoid the release of the toxic free Gd(III). ${ }^{1}$ Several pathways leading to the potential dissociation of $\mathrm{Gd}^{3+}$ complexes in vivo have been identified: 1) acid-catalyzed dissociation; 2) dissociation catalyzed by endogenous metal ions such as $\mathrm{Zn}^{2+}$ and $\mathrm{Cu}^{2+}$ and 3) dissociation assisted by endogenous ligands like citrate, phosphate or bicarbonate. Accordingly, the continuous search for new CAs with increasing stability and relaxivities respect to the commercial ones is still a challenge. In this sense, it should be noted that several gadolinium CAs have shown not only to be stables in the presence of $\mathrm{Zn}{ }^{\text {II }}$ but to improve their relaxation time. ${ }^{2,3}$

With these considerations in mind, in this work we prepare the new ligand $\mathrm{H}_{3} \mathrm{~L}$ (Scheme 1), with predesigned compartments to allocate $3 d$ and $4 f$ ions, with the aim of isolating a $\mathrm{ZnGd}$ heretonuclear complex and evaluate its ability to act as CA for MRI.

\section{Results and discussion}

$\mathrm{H}_{3} \mathrm{~L}$ was obtained according to Scheme 1

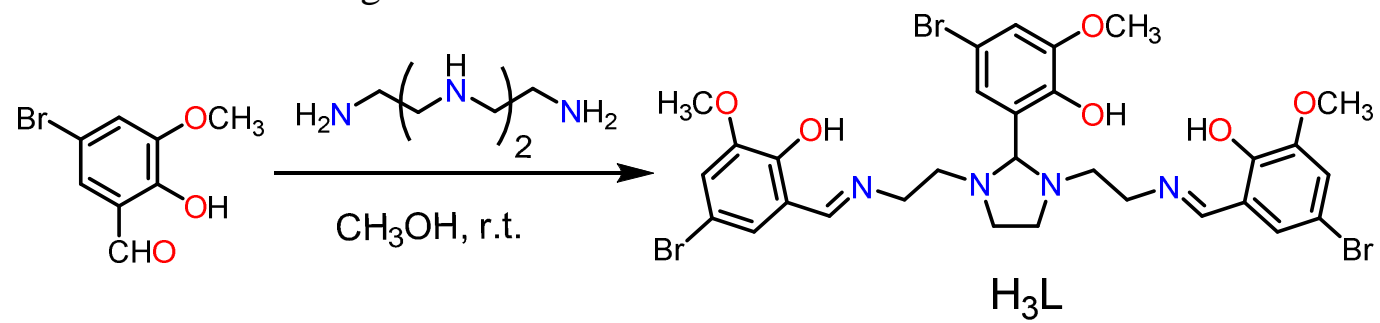

\section{Scheme 1}

Analytical and spectroscopic data corroborate the isolation of the desired compound, with high purity, and unequivocally validate the formation of the imine groups and the 
imidazolidine ring. In this way, the $\mathrm{H} 4$ and $\mathrm{H} 17$ protons (Fig. 1) appear as singlets in the ${ }^{1} \mathrm{H}$ NMR spectrum at 3.83 and $8.16 \mathrm{ppm}$, respectively, and the IR spectrum shows an intense band at $1633 \mathrm{~cm}^{-1}$, which can be assigned to $\mathrm{v}(\mathrm{C}=\mathrm{N})$.

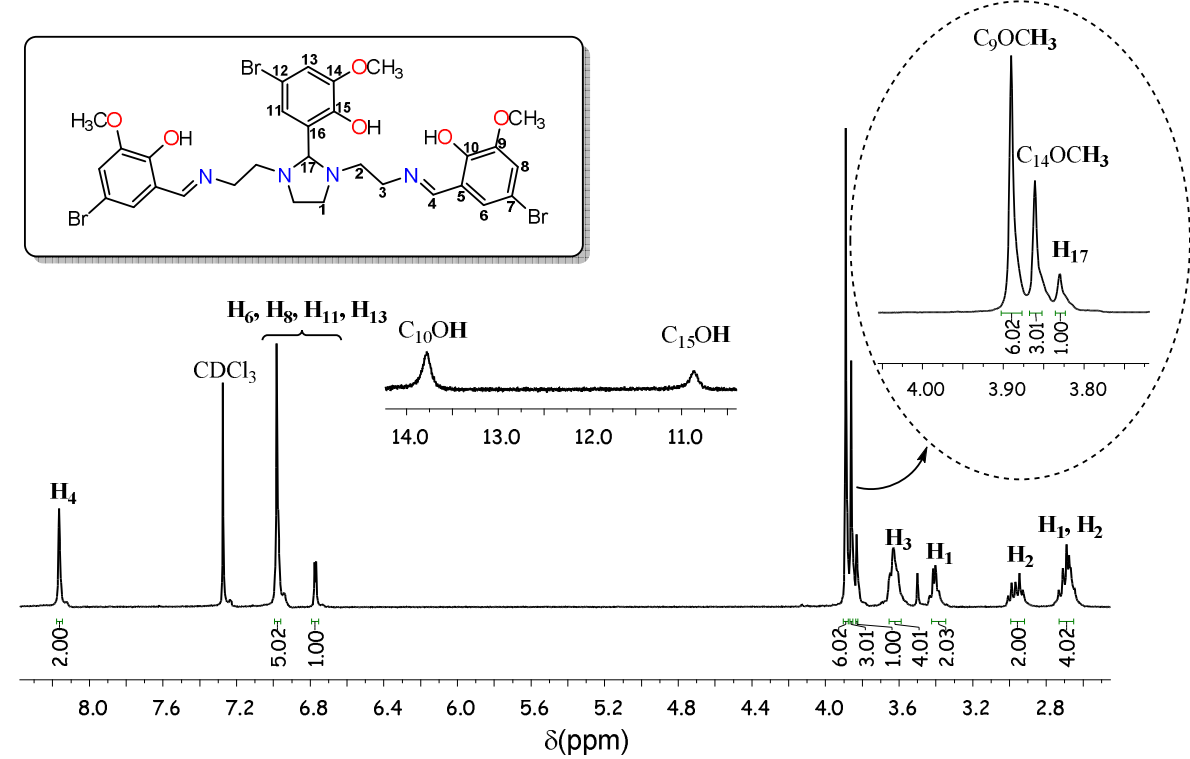

Fig. 1. ${ }^{1} \mathrm{H}$ NMR spectrum of $\mathrm{H}_{3} \mathrm{~L}$ in $\mathrm{CDCl}_{3}$

$\mathrm{H}_{3} \mathrm{~L}$ reacts with $\mathrm{Zn}(\mathrm{OAc})_{2} \cdot 2 \mathrm{H}_{2} \mathrm{O}$ and $\mathrm{Gd}\left(\mathrm{NO}_{3}\right)_{3} \cdot 6 \mathrm{H}_{2} \mathrm{O}$ in $1: 1: 1$ molar ratio to yield the heteronuclear complex $\left\{\left[\mathrm{ZnGd}(\mathrm{HL})\left(\mathrm{NO}_{3}\right)(\mathrm{OAc})\left(\mathrm{CH}_{3} \mathrm{OH}\right)\right]\left(\mathrm{NO}_{3}\right)\right\}(\mathbf{1})$, as shown in Scheme 2, which precipitates as the hexahydrate $1 \cdot 6 \mathrm{H}_{2} \mathrm{O}$.

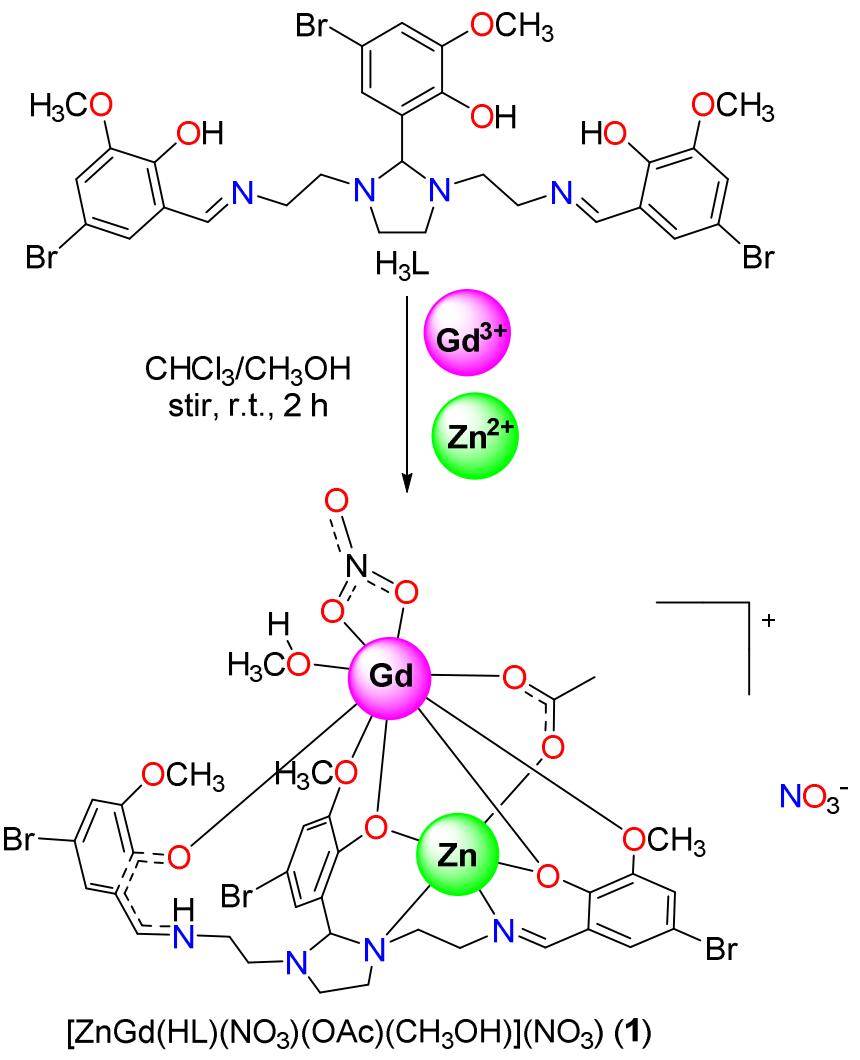

Scheme 2. Reaction scheme for isolating 1.

The analytical, spectroscopic and X-ray diffraction characterization of $\mathbf{1} \cdot 6 \mathrm{H}_{2} \mathrm{O}$ agrees with the structure proposed in Scheme 2. Thus, the comparison of the IR spectrum of the complex with that of the free ligand shows that the band assigned to $\mathrm{v}(\mathrm{C}=\mathrm{N})$ splits into two 
new bands at 1636 and $1648 \mathrm{~cm}^{-1}$, due to the loss of symmetry of the ligand in the complex. In addition, new bands are observed at $1556 \mathrm{~cm}^{-1}$, assigned to $v\left(\mathrm{COO}^{-}\right)$, and at 1300 and $1285 \mathrm{~cm}^{-1}$, assigned to $\mathrm{NO}_{3}^{-}$vibrations, in agreement with the presence of the acetate and nitrate donors in the metal complex. ${ }^{4}$ Finally, it is possible to observe a broad band centred at $3264 \mathrm{~cm}^{-1}$, which indicates the presence of water and methanol in the compound.

Several attempts to grow single crystals of $\mathbf{1} \cdot 6 \mathrm{H}_{2} \mathrm{O}$ were unsuccessful and only allowed to obtain small single crystals. Thus, X-ray diffraction studies were not of enough quality to solve the structure but they let to know the unit cell parameters, which are the following ones: crystal system: monoclinic; $a=10.82(3), b=16.29(5), c=26.67(7) \AA ; \beta=97.37(6){ }^{\circ}$; $\mathrm{V}=4659(37) \AA^{3}$. These parameters are very similar to those found for a ZnDy complex with the same ligand ${ }^{5}$ and, therefore, the structure should be very akin and should agree with the proposed one in Scheme 2.

The potentiality of $\mathbf{1} \cdot 6 \mathrm{H}_{2} \mathrm{O}$ as a MRI contrast agent was evaluated. Thus, longitudinal $R_{1}$ and transversal $R_{2}$ relaxivities were measured. The $R_{1}$ value of $4.90 \mathrm{mM}^{-1} \mathrm{~s}^{-1}$ is comparable with those found for other commercial agents, ${ }^{6}$ and, therefore, it could be said that $1 \cdot 6 \mathrm{H}_{2} \mathrm{O}$ should be a good $T_{1}$ contrast agent. Nevertheless, the $R_{2}$ value is $38.63 \mathrm{mM}^{-1} \mathrm{~s}^{-1}$, and, therefore, the $T_{1} / T_{2}\left(R_{2} / R_{1}\right)$ ratio is 7.9 , value that strongly differs from 1 . As a consequence, this precludes the use of $\mathbf{1} \cdot 6 \mathrm{H}_{2} \mathrm{O}$ as a positive MRI contrast. ${ }^{7}$ However, the $R_{2}$ value is also quite large and the $T_{1} / T_{2}$ ratio is higher than 6 , which is a condition for a species being used as a $T_{2}$ contrast agent. Accordingly, it seems that this heteronuclear $\mathrm{ZnGd}$ complex could be a candidate as a negative MRI contrast, in spite of usual $T_{2}$ agents are based, for example, on magnetic iron oxide nanoparticles. ${ }^{8}$

The potential of the GdZn system to serve as contrast agent was also demonstrated using in vitro MRI on tube phantoms. The MRI experiments were conducted using a reference without complex (at 12 o'clock in phantoms, see Fig. 2) and six different increasing concentrations (clockwise) of the synthesized complex (0.05, 0.2, 0.5, 1, 1.2 and $1.5 \mathrm{mM}$ ).

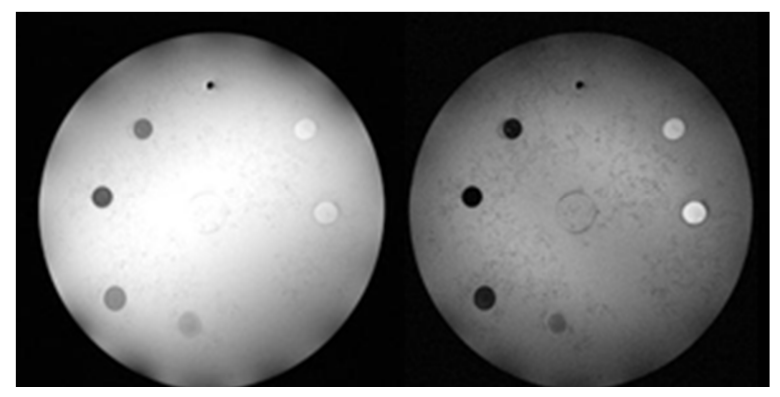

Fig. 2. $T_{1}$-weighted (left) and $T_{2}$-weighted (right) $\mathrm{MR}$ images for $1 \cdot 6 \mathrm{H}_{2} \mathrm{O}$

The $T_{1}$-weighted phantom shows that a bright image can be gradually obtained by increasing the complex concentration up to $0.5 \mathrm{mM}$; in contrast, at higher concentrations the image becomes darker. On the other hand, the $T_{1}$-weighted phantom darkens as the concentration increases. Accordingly, this seems to indicate that, as previously anticipated on the basis of the $T_{1} / T_{2}$ ratio, $1 \cdot 6 \mathrm{H}_{2} \mathrm{O}$ has a better performance as a $T_{2}$ contrast agent.

\section{Conclusions}

The new $\mathrm{H}_{3} \mathrm{~L}$ ligand, with differentiated compartments for $3 d$ and $4 f$ metal ions, has been satisfactorily isolated and characterized. The ligand yields the heteronuclear $\mathrm{ZnGd}$ complex $\left\{\left[\mathrm{ZnGd}(\mathrm{HL})\left(\mathrm{NO}_{3}\right)(\mathrm{OAc})\left(\mathrm{CH}_{3} \mathrm{OH}\right)\right]\left(\mathrm{NO}_{3}\right)\right\} \cdot 6 \mathrm{H}_{2} \mathrm{O}$. This complex shows longitudinal relaxivities comparable to those of commercial $T_{1}$ CAs but the $T_{1} / T_{2}$ ratio considerable higher than 1 indicates that it is not a good candidate for being used as a positive MRI contrast agent. Nevertheless, the relatively high transversal relaxivity $R_{2}$ and the $T_{1} / T_{2}$ ratio higher than 6 suggest a better performance as magnetic negative imaging contrast agent. These results are validated by in vitro MRI phamtons. 


\section{Experimental}

\section{Synthesis of $\mathrm{H}_{3} L$}

$\mathrm{H}_{3} \mathrm{~L}$ was isolated as follows: to a solution of 5-bromo-2-hydroxybenzaldehyde (1.386 g, 6 $\mathrm{mmol})$ in methanol $(40 \mathrm{~mL})$, triethylentetramine $(0.292 \mathrm{~g}, 2 \mathrm{mmol})$. The solution was stirred in air for $4 \mathrm{~h}$. and a yellow solid precipitated, being subsequently filtered off and dried in air 1.2 g (76\%). MW: 785.32 gmol $^{-1}$. M.P.: 200-202 ${ }^{\circ} \mathrm{C}$. Elemental analysis: experimental: C 45.89, N 6.96, $\mathrm{H} 4.25 \%$; calcd. for $\mathrm{C}_{30} \mathrm{H}_{33} \mathrm{~N}_{4} \mathrm{O}_{6} \mathrm{Br}_{3}$ : C 45.88, N 7.13, $\mathrm{H}$ 4.23. IR spectrum $\left(\mathrm{ATR}, \tilde{\mathrm{v}} / \mathrm{cm}^{-1}\right): 1633(\mathrm{C}=\mathrm{N}) .{ }^{1} \mathrm{H} \mathrm{NMR}\left(250 \mathrm{MHz}, \mathrm{CDCl}_{3}, \delta \mathrm{ppm}\right): 2.65-2.74(\mathrm{~m}, 4 \mathrm{H}$, $2 \mathrm{H} 1+2 \mathrm{H} 2) ; 2.93-3.01(\mathrm{~m}, 2 \mathrm{H}, 2 \mathrm{H} 2) ; 3.43-3.38(\mathrm{~m}, 2 \mathrm{H}, 2 \mathrm{H} 1) ; 3.61(\mathrm{t}, 4 \mathrm{H}, 4 \mathrm{H} 3) ; 3.83(\mathrm{~s}, 1 \mathrm{H}$, $\mathrm{H} 17) ; 3.86\left(\mathrm{~s}, 3 \mathrm{H}, \mathrm{CH}_{3}\right) ; 3.89$ (s, 6H, 2CH$) ; 6.77(\mathrm{~s}, 1 \mathrm{H}, \mathrm{H} 11) ; 6.95-7.01(\mathrm{~m}, 5 \mathrm{H}, 2 \mathrm{H} 6+2 \mathrm{H} 8$ $+\mathrm{H} 13) ; 8.16(\mathrm{~s}, 2 \mathrm{H}, 2 \mathrm{H} 4) ; 10.86(\mathrm{~s}, 1 \mathrm{H}, \mathrm{OH}) ; 13.78(\mathrm{~s}, 2 \mathrm{H}, 2 \mathrm{OH}) . \mathrm{RMN}^{-1} \mathrm{H}(250 \mathrm{MHz}$, DMSO- $d_{6}, \delta$ ppm): 2.57-1.69, 2.71-2.80 (m, 6H, 2H1 + 4H2); 3.27-3.34 (m, 2H, 2H1); 3.53$3.65(\mathrm{~m}, 4 \mathrm{H}, 4 \mathrm{H} 3) ; 3.71\left(\mathrm{~s}, 3 \mathrm{H}, \mathrm{CH}_{3}\right) ; 3.77\left(\mathrm{~s}, 6 \mathrm{H}, 2 \mathrm{CH}_{3}\right) ; 4.09(\mathrm{~s}, 1 \mathrm{H}, \mathrm{H} 17) ; 6.94(\mathrm{~s}, 1 \mathrm{H})$, $6.97(\mathrm{~s}, 1 \mathrm{H})(\mathrm{H} 11+\mathrm{H} 13) ; 7.06(\mathrm{~s}, 2 \mathrm{H}), 7.18(\mathrm{~s}, 2 \mathrm{H})(2 \mathrm{H} 6+2 \mathrm{H} 8) ; 8.34$ (s, 2H, 2H4).

\section{Synthesis of $\left\{\left[\mathrm{ZnGa}(\mathrm{HL})\left(\mathrm{NO}_{3}\right)(\mathrm{OAc})\left(\mathrm{CH}_{3} \mathrm{OH}\right)\right]\left(\mathrm{NO}_{3}\right)\right\} \cdot 6 \mathrm{H}_{2} \mathrm{O}\left(\mathbf{1} \cdot 6 \mathrm{H}_{2} \mathrm{O}\right)$}

To a $\mathrm{CHCl}_{3}(5 \mathrm{~mL})$ solution of $\mathrm{H}_{3} \mathrm{~L}(0.074 \mathrm{~g}, 0.094 \mathrm{mmol}), \mathrm{Zn}(\mathrm{OAc})_{2} \cdot 2 \mathrm{H}_{2} \mathrm{O}(0.021 \mathrm{~g}, 0.094$ mmol) was added. Then, to the resultant yellow solution $\mathrm{Gd}\left(\mathrm{NO}_{3}\right)_{3} \cdot 6 \mathrm{H}_{2} \mathrm{O}(0.042,0.094$ $\mathrm{mmol}$ ) and $5 \mathrm{~mL}$ of methanol were added. The mixture was stirred at room temperature for $2 \mathrm{~h}$ and a finely divided yellow powder is obtained. The solid is separated by centrifugation and dried in air. $072 \mathrm{~g}(58 \%)$. MW: $1329.12 \mathrm{gmol}^{-1}$. Elemental analysis: experimental: C 29.35, N 6.54, H 3.24\%; calcd. For $\mathrm{ZnGdC}_{33} \mathrm{H}_{50} \mathrm{~N}_{6} \mathrm{O}_{21} \mathrm{Br}_{3}$ : C 29.82, N 6.32, H 3.79\%. IR spectrum (ATR, $\left.\tilde{v} / \mathrm{cm}^{-1}\right)$ : 1636, $1648(\mathrm{C}=\mathrm{N}) ; 1557\left(\mathrm{COO}^{-}\right) ; 1285,1300\left(\mathrm{NO}_{3}{ }^{-}\right) ; 3264(\mathrm{OH})$.

\section{MRI measurements}

MRI studies at high magnetic field were conducted on a 9.4 T MR system (Bruker Biospin, Ettlingen, Germany) with $440 \mathrm{mT} / \mathrm{m}$ gradients. A quadrature radio-frequency transmit-receive resonator was used for data acquisition. $T_{2}$-weighted images were acquired using a multi slice multi echo sequence of $11.32 \mathrm{~ms}$ echo time, $3000 \mathrm{~ms}$ repetition time, 16 echoes, 14 slices, 1 average, FOV of $7.5 \mathrm{~cm} \times 7.5 \mathrm{~cm}$ and matrix size of $300 \times 300 . T_{1}$-weighted images were acquired using a RARE-VTR sequence of $10.81 \mathrm{~ms}$ echo time, rare factor 4, repetition times of $3000 \mathrm{~ms}, 3235 \mathrm{~ms}, 3491 \mathrm{~ms}, 3770 \mathrm{~ms}, 4078 \mathrm{~ms}, 4422 \mathrm{~ms}, 4810 \mathrm{~ms}, 5256 \mathrm{~ms}, 5779 \mathrm{~ms}$, $6414 \mathrm{~ms}, 7221 \mathrm{~ms}, 8327 \mathrm{~ms}, 10098 \mathrm{~ms}$ and $15000 \mathrm{~ms}$. 14 slices, 1 average, FOV of $7.5 \mathrm{~cm} \mathrm{X}$ $7.5 \mathrm{~cm}$ and a matrix size of $300 \mathrm{X} 300$. Post-processing was performed using ImageJ software (Rasband, W. NIH).

\section{References}

1. The Chemistry of Contrast Agents in Medical Magnetic Resonance Imaging (Eds: A. E. Merbach, L. Helm, Ê. Tûth), Wiley, Hoboken, 2013, $2^{\text {o Ed. }}$

2. J. Yu, A. F. Martins, C. Preihs, V. Clavijo-Jordan, S. Chirayil, P.Zhao, Y. Wu, K. Nasr, G.

E. Kiefer, A. D. Sherry, J. Am. Chem. Soc. 2015, 137, 14173-14179.

3. M. Regueiro-Figueroa, S. Gündüz, V. Patinec, N. K. Logothetis, D. Esteban-Gómez, R. Tripier, G. Angelovski, C. Platas-Iglesias, Inorg. Chem. 2015, 54, 10342-10350.

4. K. Nakamoto, Infrared and Raman Spectra of Inorganic and Coordination Compounds, Ed. John Wiley \& Sons, New York, 1997.

5. J. Corredoira, MSc Project, University of Santiago de Compostela, 2016.

6. A. N. W. Kuda-Wedagedara, M. J. Allen, Analyst 2014, 139, 4401-4410.

7. L. Helm, Future Med. Chem. 2010, 2, 385-396.

8. H. Shokrollahi, Mater. Sci. Eng. C-Mater. Biol. Appl. 2013, 33, 4485-4497. 